EMILIJA NIKOLIĆ

Institute of Archaeology Belgrade

E-mail: e.nikolic@ai.ac.rs

JELENA ANĐELKOVIĆ GRAŠAR

Institute of Archaeology Belgrade

E-mail: j.andjelkovic@ai.ac.rs
Received: November $14^{\text {th }} 2020$

Accepted: December $10^{\text {th }} 2020$

Original research article

911.37:622.332(497.11)"1870/2020"

351.85:725(497.11)

COBISS.SR-ID 29133065

https://doi.org/10.18485/arhe_apn.2020.16.10

\title{
HERITAGE WE PRETEND NOT TO SEE: AN OLD MINING COMMUNITY IN THE VILLAGE OF KOSTOLAC, SERBIA
}

\begin{abstract}
In addition to Viminacium, an internationally recognized Roman archaeological site and park, there are many other elements of cultural heritage in the Kostolac village situated in northeastern Serbia near the Danube, which are almost unknown for most of the people in Serbia and beyond.

This year, 2020, marks the 150th anniversary of the opening of coal exploitation in the Kostolac village, and the official beginning of the industrialisation of Serbia, determined by this event in 1870. Unfortunately, the remains of the buildings in the mining community which witnessed an important part of the modern development of the country are in the state of ruin, and have been slowly disappearing after the closing of the underground coal exploitation in 1966, following the rapid development of modern strip mining and electric generation. Also, many spiritual elements in the life of Kostolac people connected to the mining are not widely recognized as values, although they represent the precious intangible heritage of this village and whole region.
\end{abstract}

KEYWORDS: KOSTOLAC VILLAGE, MINING COMMUNITY, MINING HERITAGE, INDUSTRIAL HERITAGE, UNDERGROUND MINE, COAL MINING.

\section{INTRODUCTION}

The agricultural fields of Kostolac village (village of Stari Kostolac), in the immediate vicinity of the town of Kostolac, near the city of Požarevac in northeastern Serbia along the Danube, the place of connections and divisions of peoples throughout history, spread across the area where the territory of Viminacium - the Roman city and the legionary fortress once existed. At this place, intensive strip coal mining and electricity generation have been carried out for decades, resulting in the disappearance of ancient buildings and the loss of large areas of some of the most fertile land in Serbia which hides historic remains, but also layers of coal, deep underneath.

In addition to Viminacium, an internationally recognized archaeological site and park (Nikolić, Anđelković Grašar and Rogić 2017; Anđelković Grašar, Rogić and Nikolić 2013: 267-271) proclaimed cultural property of exceptional importance for the Republic of Serbia in 1979 (Одлука 1979; Одлука 2009), and part of the international cultural property Frontiers of the Roman Empire being on the Tentative UNESCO World Heritage List (UNESCO WHS List; Korać et al. 2014) since 2015, there are many other elements of cultural heritage on the territory of Kostolac village, 


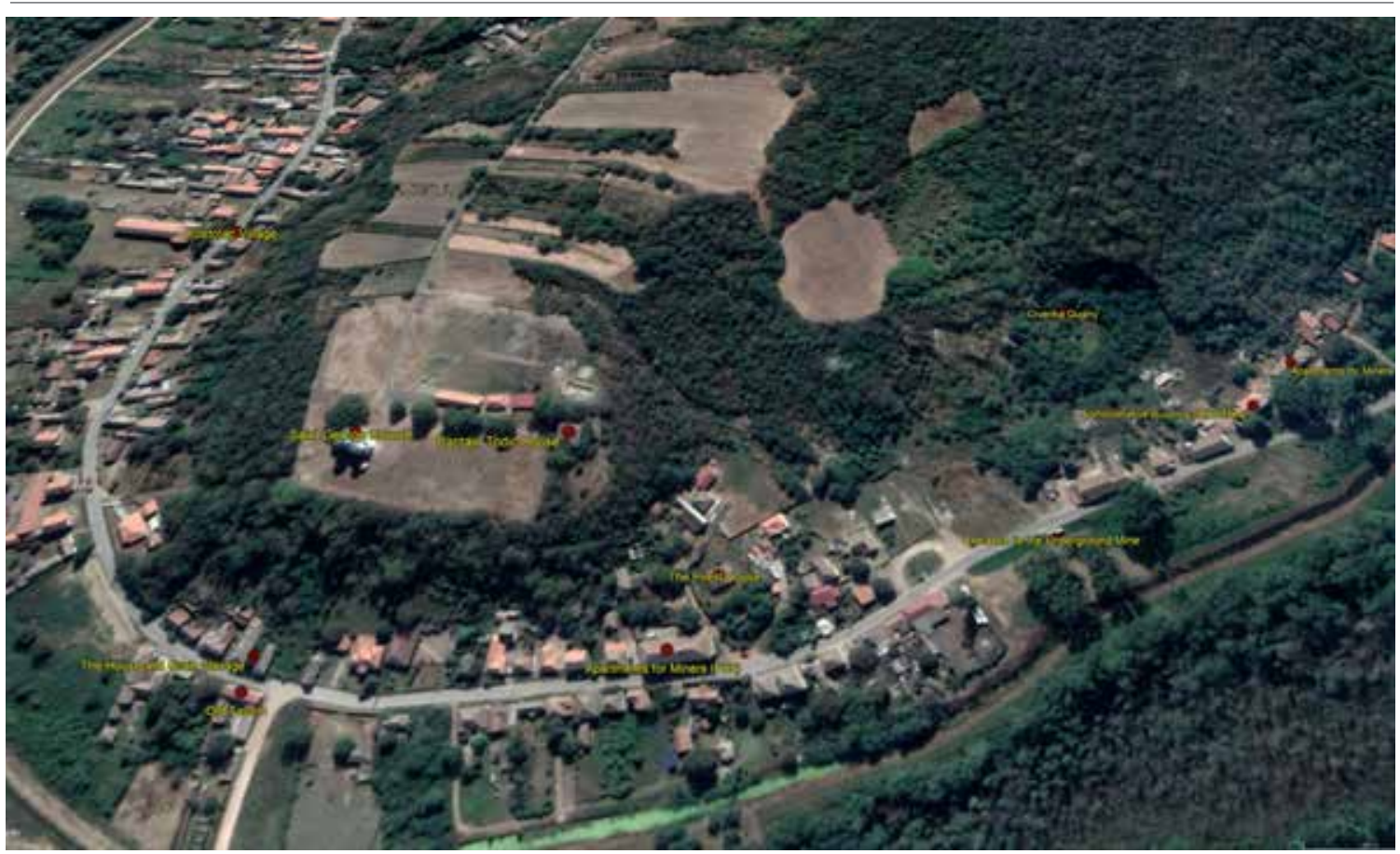

Fig. 1. Arial view of the residential part of Kostolac village with preserved mining community buildings (Tags: the authors on Google Earth Pro photo printed on November 27, 2020 - historical image from 2020).

which are almost unknown for most of the people in Serbia and beyond. On the plateau above the village there are the remains of the medieval town of Braničevo, dated to a period from the 11th to the 13th century (Поповић и Иванишевић 1988: 167168; D’Amato and Spasić-Đurić 2018, 29-32; Spasić-Đurić and Jovanović 2018: 151-155), as well as the Church of St. George built from 1923 to 1925 (Богдановић 1928, 46-48), while in the residential part of the village there are several traditional historic houses. The wide area of the village cemetery has a continuity of burial from the 4th century BC (Korać and Mikić 2014: 13-14;) up until today. This village is the place where underground coal exploitation started in 1870, representing an event marking the beginning of the industrialisation of Serbia (Вучетић 2010: 11), and where the remains of the buildings of the former mining community around the old mine shaft are situated. Unfortunately, with the exception of Viminacium and the Church, all cultural properties in the village are still only under prior protection (Просторни план 2015: 65-66) and are mostly decaying.
In terms of tangible heritage elements connected to the old mining community, there is the former entrance to the oldest mine shaft "St. George" closed as early as 1933 (Јовановић, Паклар и hосић 1971: 94) with a coal wagon, several houses with apartments for miners, private houses from the same period, as well as an old tavern and administrative building of the mine, while on the hill above the village next to the Church there is the villa of the river captain Dragutin Todić (1880-1928), who was transporting Kostolac coal along the Danube. The Church of St. George was the captain's endowment as well as the house for the village priest (Богдановић 1928: 46-48, 70) (Fig. 1-Fig. 9).

The intangible heritage elements are represented by stories of buried treasures, demonic characters and mythical creatures, cults of sacred trees and medicinal springs, village saints' celebrations, various toponyms, centuries-old use of natural resources whose wealth led to the development of agricultural and building activities, as well as the diverse ethnic structure (Nikolić 2018: 170). Many of these can be connected to the mining. 


\section{MINING HISTORY REMAINS AS HERITAGE}

The development of the mining industry in the Kostolac area has been a driver of rapid development for the entire Požarevac region since the 19th century (Nikolić 2018, 520). In 1870, coal was found in a test shaft, and in 1873 the privilege of opening a mine in Kostolac was issued to the owner of a steam mill and spirit factory in Belgrade, the Czech Franja Všetečka (Анђелковић 2010: 15; Grgašević 1923: 5). However, in 1881 Đorđe Vajfert (1850-1937), industrialist and later lifetime Honorary Governor of the National Bank of the Kingdom of Serbia and the National Bank of the Kingdom of Serbs, Croats and Slovenes, became the owner of the mine. Together with the Czech engineer Franjo Šistek (1854-1907) he developed it significantly (Анђелковић 2010: 133) as well as the mining community for its workers (Пејић и Јаношевић 1971: 63; Симић 1971: 77 78; Grgašević 1923: 15). In 1889, the Kostolac mine was the only one in Serbia with permanent production and exports of coal while Serbian industry and traffic were almost entirely operating on its basis (Пејић и Јаношевић 1971: 64).

Except for buildings for the accommodation of managers, staff, workers and miners, many industrial facilities with a river dock were built in the village of Kostolac. The electric plant produced electricity to illuminate the village and operate machinery in the mine (Вучетић 2010: 15). In order to exploit the mine's fine coal, a factory of bricks and roof tiles was built in 1885 . Its products were used for the erection of buildings in the community, but it was soon closed because it could not withstand the competition of small, peasant manufacturers. The steam mill built in 1890 worked until the mid 1950s (Пејић и Јаношевић 1971: 63, 68-69). The glass factory erected in 1906 produced flat glass and packaging products but was destroyed in the First World War. The City park in Požarevac was decorated with amorphous clumps of raw glass mass remaining after the factory's demolition, between the two world wars (Фелдић 1990: 223), while the building material left over was used for the construction of industrial buildings in the nearby Kostolac area (Влашковић и Славковић 1971: 117). Several decades after the Second World War, all industrial facilities of the Kostolac mine disappeared, and the mining community fell into ruins (Fig. 3).

The appearance of the mining community in the village of Kostolac is evidenced by a few photographs and drawings, as well as by several records of travel writers from the 19th century (Nikolić 2018: 162; Стојковић 1893: 158-159; Каниц 1989: 190). The peasant village of Kostolac had 212 homes in 1887, while the workers' community had ten residential buildings for miners, a few private residential buildings, a tavern, a mine administration building, a butcher's shop, and a grocery store (Фелдић 1971: 214-215). At the end of 1902, the mine owned 626 ha of land and a community of over twenty buildings (Симић 1971: 84-85). From the beginning of the 1930s, a library and reading room in the village and the mine were established, with a choir of peasants and miners as well as a mining drama section. There was also a tamburitza orchestra, which was founded in 1927 and lasted until the period close to the beginning of the Second World War (Шегрт 1971: 231-234) (Fig. 4). In 1939, it was noted that the village of Kostolac had many craft shops, among which were four tailor's shops, the only shops of this kind in all villages of the Požarevac area. Also, there was a medical institution in the village and the mine itself had its own doctor. The only sport club in the whole rural area of Požarevac was the football club "St. George" in the village of Kostolac, with miners as its players (Вуловић 1939: 52-57).

Apart from traditional rural and townhouses, a worker's house was an important form of housing. As in other mining areas of Serbia, community flats built during the 19th and the first half of the 20th century in the village of Kostolac represent a "distinctive element of mining culture". They 

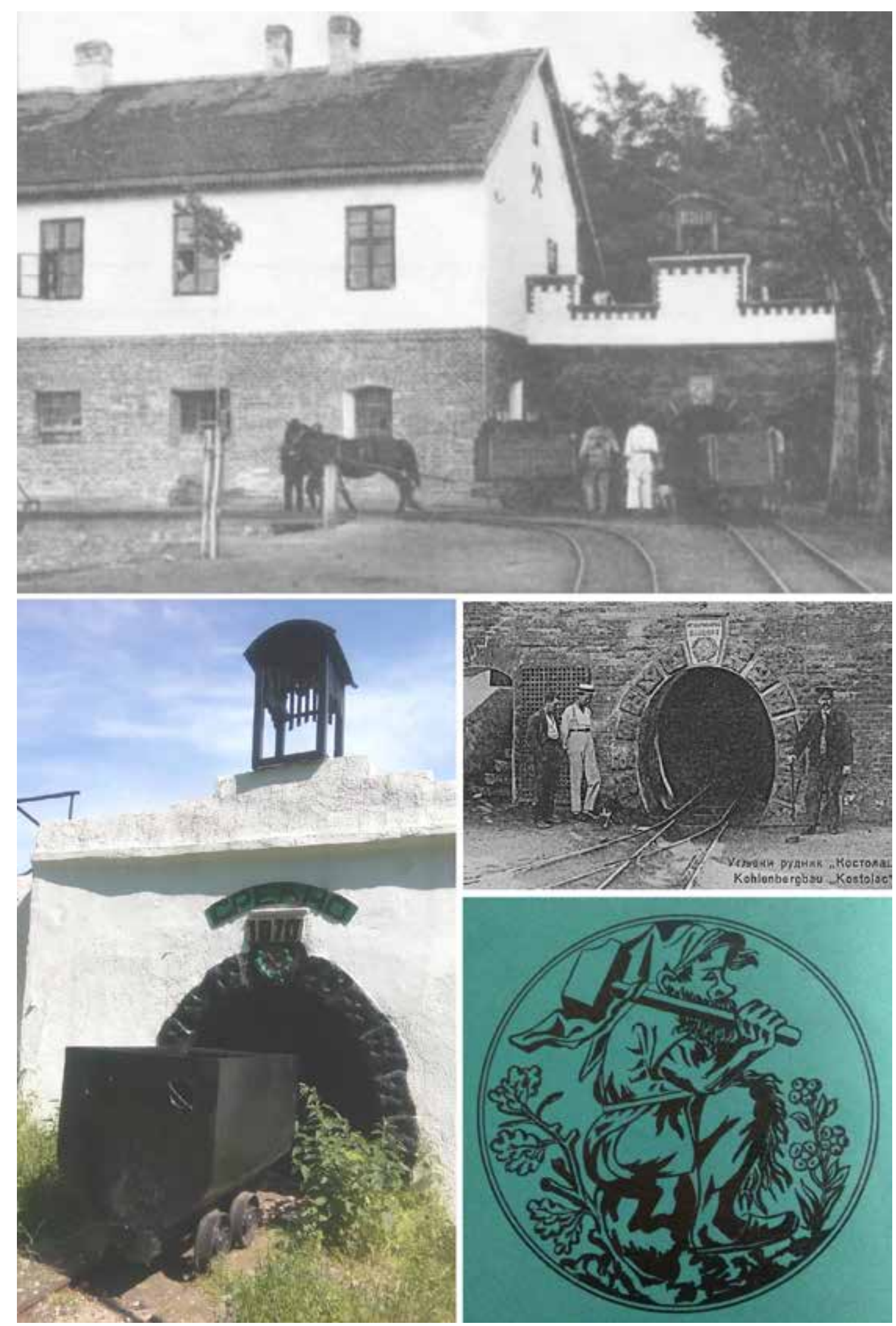

Fig. 2. Entrance to the underground mine shaft. Up: the entrance with the surrounding area in the end of the 19th century (Simić 1971, 79); down left: the entrance today (the photo made by the authors in 2017); middle right: the old photo of the entrance (Simić 1971, 99). Down right: Badža the Dwarf as seen by the artists (Marković 1971, 6). 
were created according to the specific way of life of the miners and the change of life of the peasantry (Ромелић 2000: 225-226). The community represented a kind of "urban agglomeration" that differed in content and form from its rural ambient. Although created at different times and under different conditions, the village and community soon became the entity we recognize today as the village of Kostolac (Фелдић 1971: 214). After the foundation of the nearby town of Kostolac during the Second World War and the beginning of strip mining and extensive electricity generation in the area (Јовановић, Паклар, Ћосић 1971: 101), the miners started to move from the village and community to the town, and after the underground mine was closed in 1966, life in the community soon ended (Fig. 5).

It is evident that residential buildings for shared housing of miners in Kostolac village were built according to the same architectural plan and facade composition, having modest exterior decoration. They have small apartments accessible from the backyard porch and stairs (Fig. 3; Fig. 4). However, the main administrative building of the mine was designed as a monumental facility with more complex composition and ornamental facade which is also visible on some other small mine buildings (Fig. 7a). Architectural values of these buildings should be carefully researched in future studies, always having in mind that they are connected to historic, social, artistic, cultural, technical, technological, and many other aspects of a building creation, existence and eventually, abandonment.

The wider Kostolac area has been inhabited for millennia, and throughout its history various peoples have met and mixed here, leaving their traces in it (Nikolić 2018: 195), from Roman Viminacium as a cosmopolitan centre of the time, to the Kostolac town built in the 20th century. In the 19th century, the first Serbian miners lacked expertise and experience, so apart from the locals, miners and engineers from Europe started to work in the Kostolac mine, including settlers from the present-day Czech Republic and Banat region. The original gap and mistrust of Serbian farmers who became miners towards the settlers disappeared, friendships and family ties were formed, while the habits of the settlers slowly merged with local customs (Шегрт 1971: 231). In 1878, the Czech Slavibor Brojer opened the first school in the village (Вучетић 2010: 41). The Slovenes, together with other former miners from today's Croatia, Slovakia, and Austria came to the village of Kostolac during the First World War as Austro-Hungarian soldiers were sent to work in the mine because most of the farmer miners were mobilized into the Serbian army. In the period between the two wars, a new population of Slovenian origin immigrated with the engineers to the mine (Шегрт 1971: 231). Most of the miners from the village mine and their descendants today inhabit the town of Kostolac (Fig. 6).

Many spiritual elements of the life of Kostolac people are connected to the mine. Beliefs in imagined beings of supernatural power are deeply rooted throughout northeastern Serbia (Зечевић 1981: 8). Badža the Dwarf is a demonic character found in the stories of Kostolac village, actually being a variant of the mining demon present in European underground mining sites, having many different names (Толстој и Раденковић 2001: 506-508) (Fig. 2). The wealth of ancient remains in the vicinity of Kostolac led to the connection of many places with buried treasures. The toponyms kept traces of different peoples living in the area (Ђокић и Јацановић 1992: 61-110) and all had in common their attachment to land and nature, expressed through agriculture and other exploitations of natural resources, while maintaining traditional crafts - including brick production, active in the area from the Roman period to the present day (Nikolić 218: 209-210, 519-520). The deposit of the natural building material locally called "crvenka" ("reddish") has been used in the area of Kostolac throughout history and is situated along with the former underground mine. It represents a layer of rock that underwent metamorphism due 

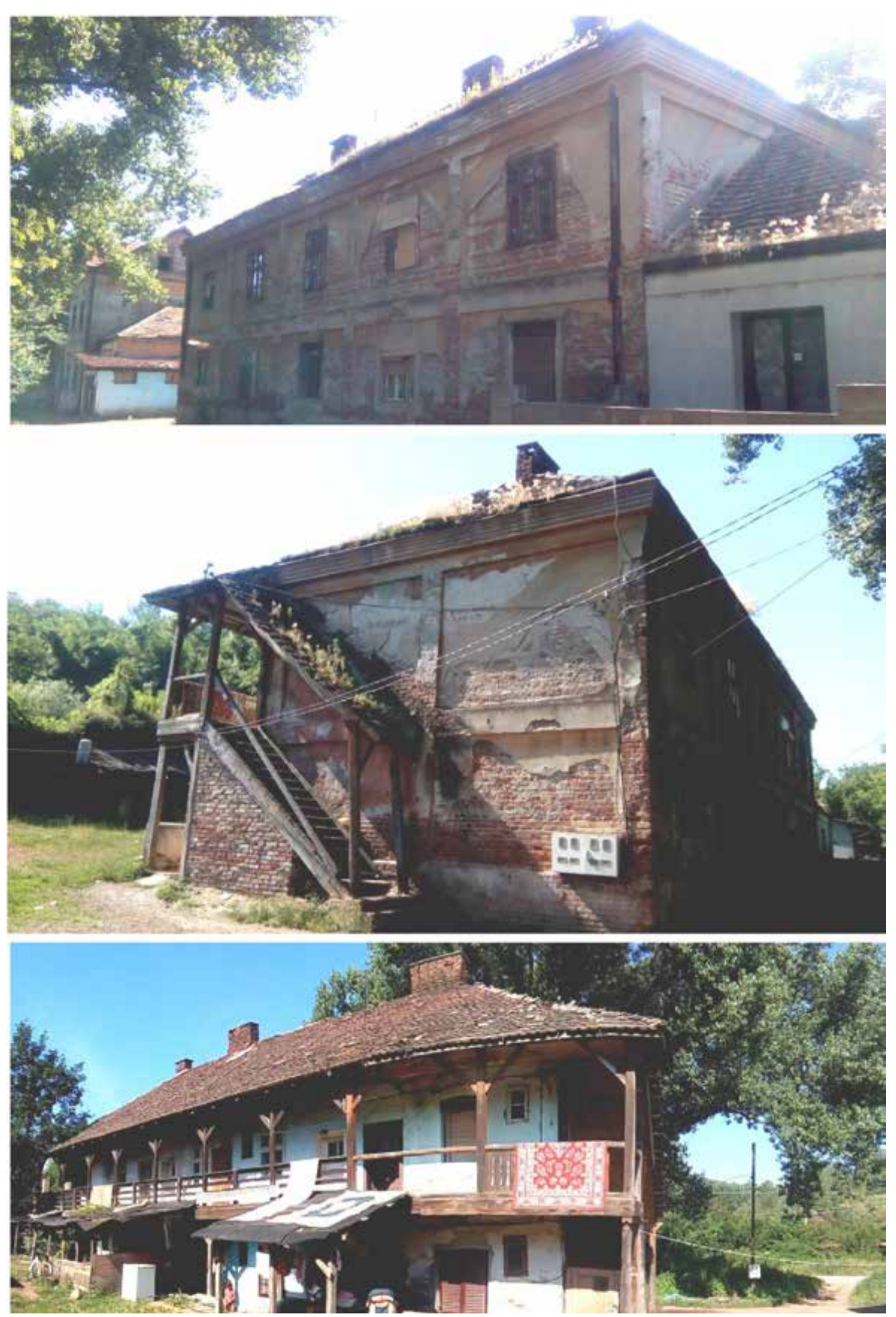

Fig. 3. Apartments for the miners (the photos made by the authors in 2017). 

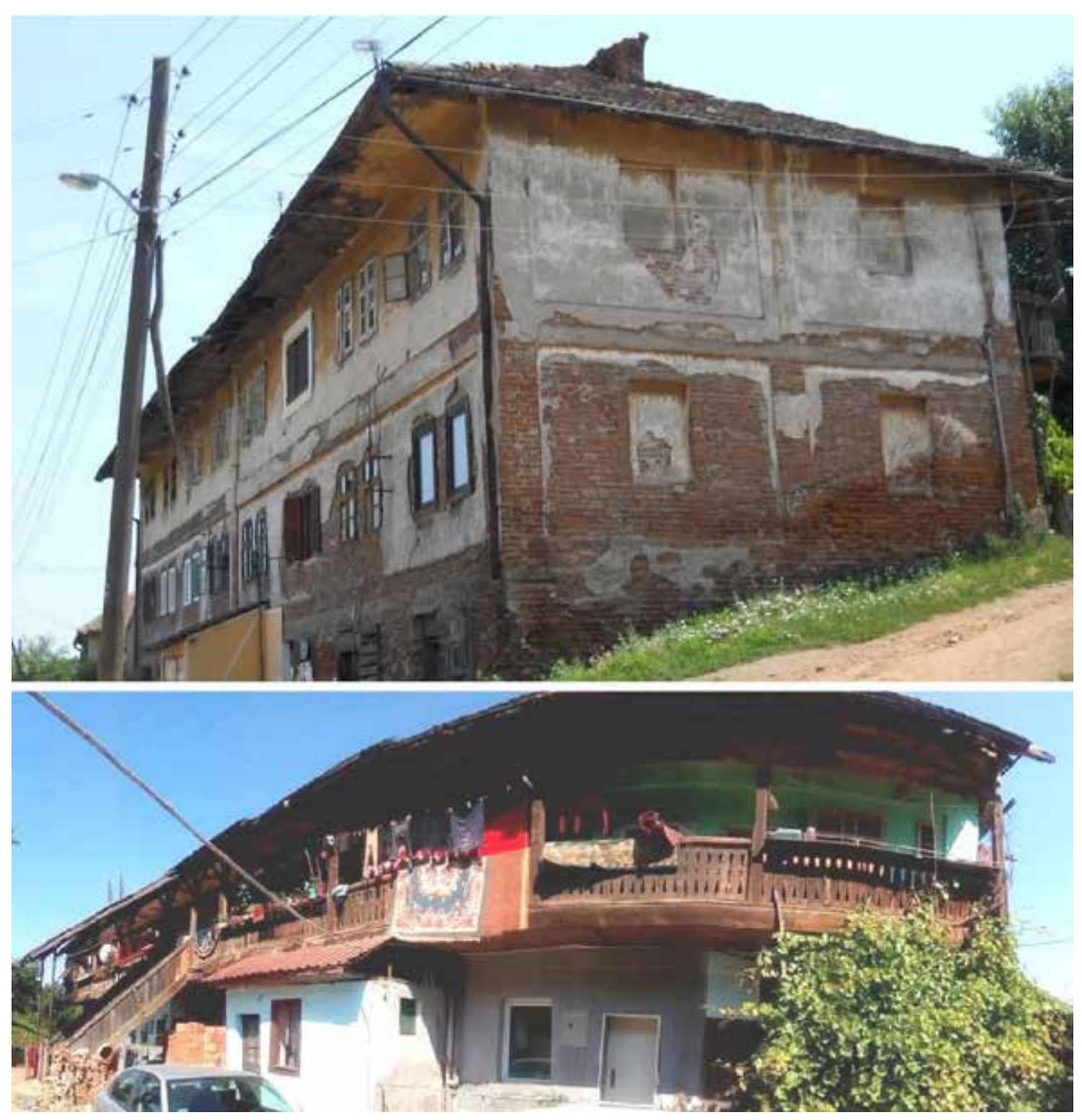

Fig. 4. Apartments for the miners (the photos made by the authors in 2017).

to the combustion of the lower coal layers after its contact with oxygen and sunlight and thus we can call it natural brick. Viminacium Romans used it for building (Nikolić 2013: 28; Nikolić, Rogić and Milovanović 2015: 66-67) and until recently it was used for covering industrial roads and making building blocks. Today, its exploitation is prohibited due to ground instability. The deposit is a valuable geoheritage, connected to the particular soil type and the existence of coal, not often encountered in the world (Nikolić 2018: 213-214;
Nikolić and Roter-Blagojević 2018: 788-789). It is also connected to the local intangible heritage, because the cause of its formation, that is, the coal self-ignition, until recently was associated with the powers of God among the villagers, although the scientific explanation for it has been known here for a long time (Nikolić 2018: 213; Nikolić, Tapavički-Ilić and Delić-Nikolić, in print). 



Fig. 5. The private house and the grain storage with the tavern and its surrounding area. Up: the area in the beginning of the 20th century (Feldic 1917, 215); middle left: the surrounding area, the private house and the grain storage today (the photos made by the authors in 2017); down: the old tavern today (the photo made by the authors in 2017). 

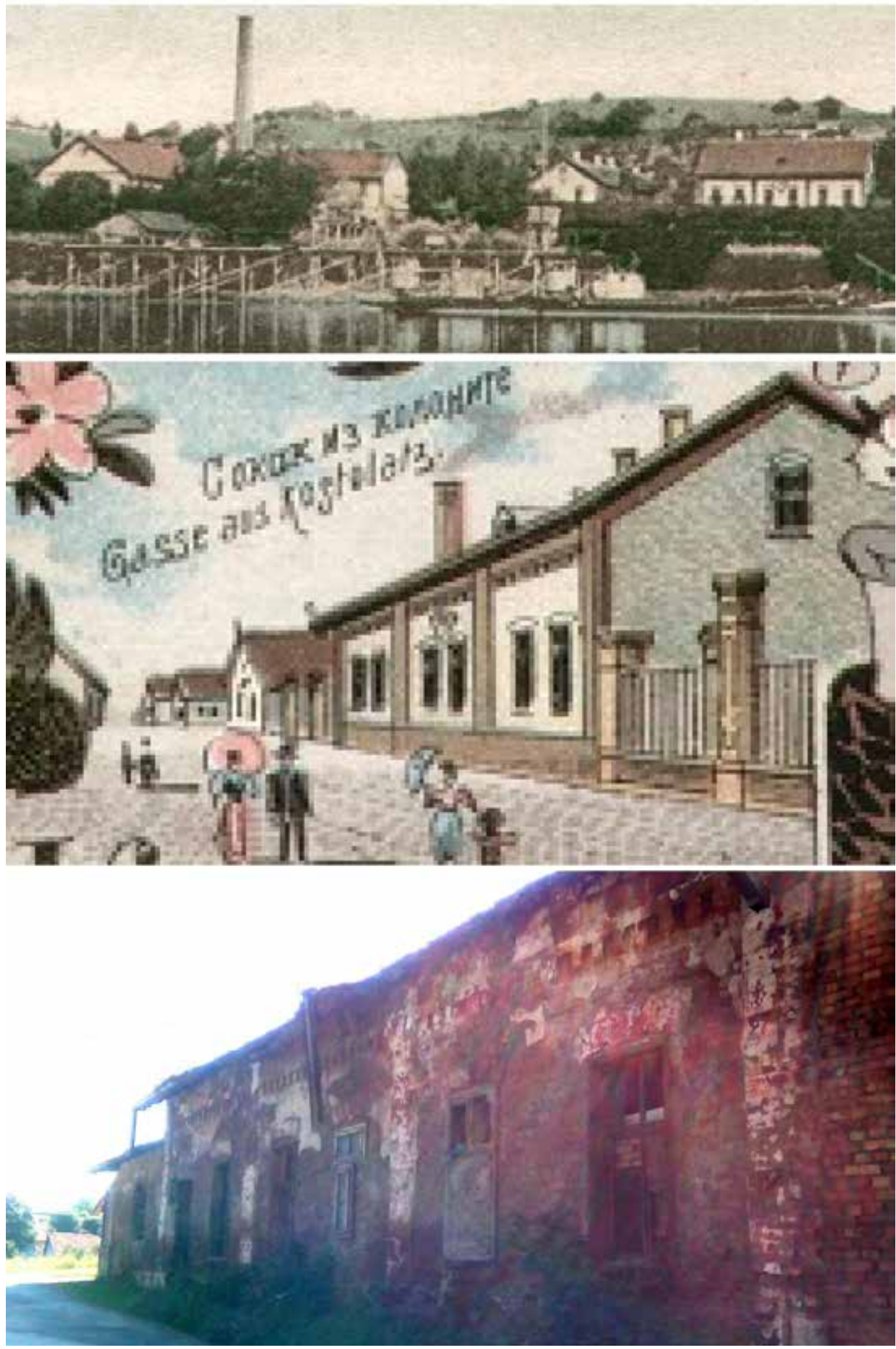

Fig. 6. One of the old buildings in the mine. Up: the mine viewed from the river in the beginning of the 20th century, with the building visible on the right (EPS); middle: the building shown on the old postcard from the beginning of the 20th century (Korać, Nikolić and Tapavički-Ilić 2016, 120, Fig.4); down: the building today

(the photo made by the authors in 2017). 
DESIRE AND OBLIGATION VS. OPPORTUNITY AND REALITY

Industrial heritage carries social value as a witness to the lives of people, and it has technological and scientific values in the history of production, engineering and construction, as well as the aesthetic value of architecture or planning (Ratkajec 2014: 253). The need for the preservation of industrial heritage has long been recognized in scientific and professional conservation communities in Serbia; some buildings and complexes are part of the European Industrial Heritage Network but still the practical protection of this heritage almost does not exist (Nikolić 2018: 492). The only coal mine in Serbia protected and presented on the network list, also having a museum, and - what is interesting, where coal exploitation is still ongoing, and where the community is still alive, is the old Senje coal mine (ERIH). However, its wide promotion failed, and visitors are rare (Nikolić 2018: 765-766). What can one expect for the Kostolac mine, whose remains are almost destroyed?

After the Second World War, the properties of Đorđe Vajfert were nationalized. The current owner of the buildings of the mining community is the Electric Power Company of Serbia, while the empty captain's villa on the hill is managed by the Church administration as well as the priest's house. A restoration project for the villa was made many years ago with the intention of adapting it to be the Museum of Medieval Braničevo, since the Church allocated it for this use by the Požarevac National Museum (Nikolić 2018: 472), whose recent excavations have shed a new light to the medieval history of the area (D'Amato and Spasić-Đurić 2018: 29-67; Spasić-Đurić and Jovanović 2018: 151-173) but the project has only remained on paper. On the other hand, the Electric Power Industry of Serbia has no economic interest in the reconstruction of buildings in the former mining community, so they have been decaying for decades, illegally inhabited by the Roma people, who settled here mostly as refu- gees after the events in the former SFR and SR Yugoslavia in the 1990s (Nikolić 2018: 202, 403, 461; Стратегија 2009: 27). For many years, closing eyes to the housing problem of Roma people and the decay of the buildings, has not only made the situation worse for them as people who lack basic living conditions, but also for the industrial heritage, which they also recognize as such (Nikolić 2018, 495). One of them said, "It's good for the museum, but not for life" (Dukić 2012: 70-73) (Fig. 3, Fig. 4, Fig. 7).

The demolition of industrial facilities from the 19th century around the old Kostolac mine and its river dock, filling the wide neighbouring area with ash during contemporary mining activities which destroyed the multilayered archaeological site of Selište (Спасић-Ђурић 2012b: 10) and the condition of the buildings in the mining community represent the relationship of the generations after the Second World War to the industrial heritage. Regardless of the type of works performed on the remaining buildings of the community by the Roma people who live in them, some of these buildings owe it to Roma families that they still survive in some way (Nikolić 2018: 403). Currently, the most important problem for any planning in this area is the resettlement of Roma people, identified in the Action Plan for Improving the Position of Roma on the Territory of the City of Požarevac from 2016 to 2020 , which has foreseen their relocation to empty rural households, but also to purpose built or renovated old buildings (Акциони план 2015: 89-94); proposals, however, have not yet been implemented (Nikolić 2018: 403-404).

In the process of rehabilitation of industrial heritage buildings, the issue of ownership and management, the provision of financial resources, and setting clear goals for future uses are very important issues, since a potential investor cannot be expected to "recognize, understand and affirm a cultural property unless he recognizes or receives adequate economic profit" (Димитријевић Марковић и Сретеновић 2008: 267, 272). Thus, the question of the destiny of Kostolac mining 
community buildings may be raised in connection with the future ownership and involvment of private sector. The development of a comprehensive adaptive reuse project and the promotion of industrial heritage in Serbia could play a key role in this, also fitting into the social responsibility policies that the buildings' owner - Electric Power Industry of Serbia - fosters throughout its work (Nikolić 2018: 461), connecting its own investments with private investors. The mining community itself is not mentioned in the official regional spatial plans, but it is recognized in the spatial plan for the Viminacium archaeological site, which emphasizes the need to preserve this valuable industrial heritage by seeking mechanisms for its inclusion in all future plans (Просторни план 2015: 60). In the spatial plan of Požarevac (Просторни план 2012: 133), a project made as a part of the plan for the permanent work suspension of a nearby village Klenovnik small strip mine was noted. The project envisages a Mining Museum with a closed collection in the existing and adapted mine administrative building and an open collection with original equipment and machines, as well as the reconstruction of the underground mining shaft (Радосављевић и др. 2014: 58-60) This project has not yet even started.

Industrial buildings are suitable environments for cultural activities and creative economies, and contributions to the preservation of this heritage in the world more often come from the initiatives of the creative sector rather than from the state. Activation of abandoned industrial buildings often helps non-affirmed professionals, connecting them with clients, and when major adaptations of the buildings occur, they generally become those who defend buildings from market interests (Čizler 2014: 27-29). The failure of the state project for the Kostolac Mining Museum shows that successful worldwide examples of smaller building reuse projects should probably be followed as well, enhancing the role of the creative sector. Even a partially restored Kostolac village mining community would be able to accommodate some creative ac- tivities that could bring further social and economic development, getting precious experiences that could help in more extensive future reuse (Nikolić and Roter-Blagojević 2018: 789). The role of local creative individuals can be very important in the future preservation of the mining community. This is supported by the existence of a large number of individuals living in the small town of Kostolac who cherish and perform fine and applied arts, as well as music culture, within numerous local art associations and rock bands (Fig. 9).

Local communities in the Kostolac area have been closely related to mining for one and a half centuries, changing it's the area's agricultural occupation during industrialization, while forming new mining communities with the miners from Europe who settled here. As in other mining areas in Serbia, where different migrations occurred, the process led to the dissapearance of an ethnically and culturally homogenous environment, and the formation of the so-called mining culture (Ромелић 2000: 226), which needs to be valued as one of the elements of Kostolac's intangible heritage. Thus the remains of the Kostolac village mining community are witnesses to the beginning of modern industry in Serbia, and to the social development of the territory in the pre and post war periods (Nikolić and Roter-Blagojević 2018: 790; Robinson 2008: 24). Interestingly, a small private museum is located in the town of Kostolac, where a former underground miner, Petko Popović, born in 1933, exhibits in his house over 3,000 mining artefacts he has collected for decades across the former SFR Yugoslavia - tools, equipment, uniforms, helmets, photographs, wagons from the 19th-century Kostolac mine, as well as over 3,500 other exhibits from the post-World War II period and the time of SFRY (Večernje Novosti Online 2015) (Fig. 10).

The Kostolac mining history is commemorated on Miners' Day on August 6th, when flowers are laid at the "St. George" shaft entrance. However, only two elements of tangible heritage that symbolize it are preserved - a mining locomo- 



Fig. 7. The main administrative building of the mine. The old river dock with the building visible on the right and its detail (Simić 1971, 86); the building today (the photos made by the authors in 2017 and 2009). 

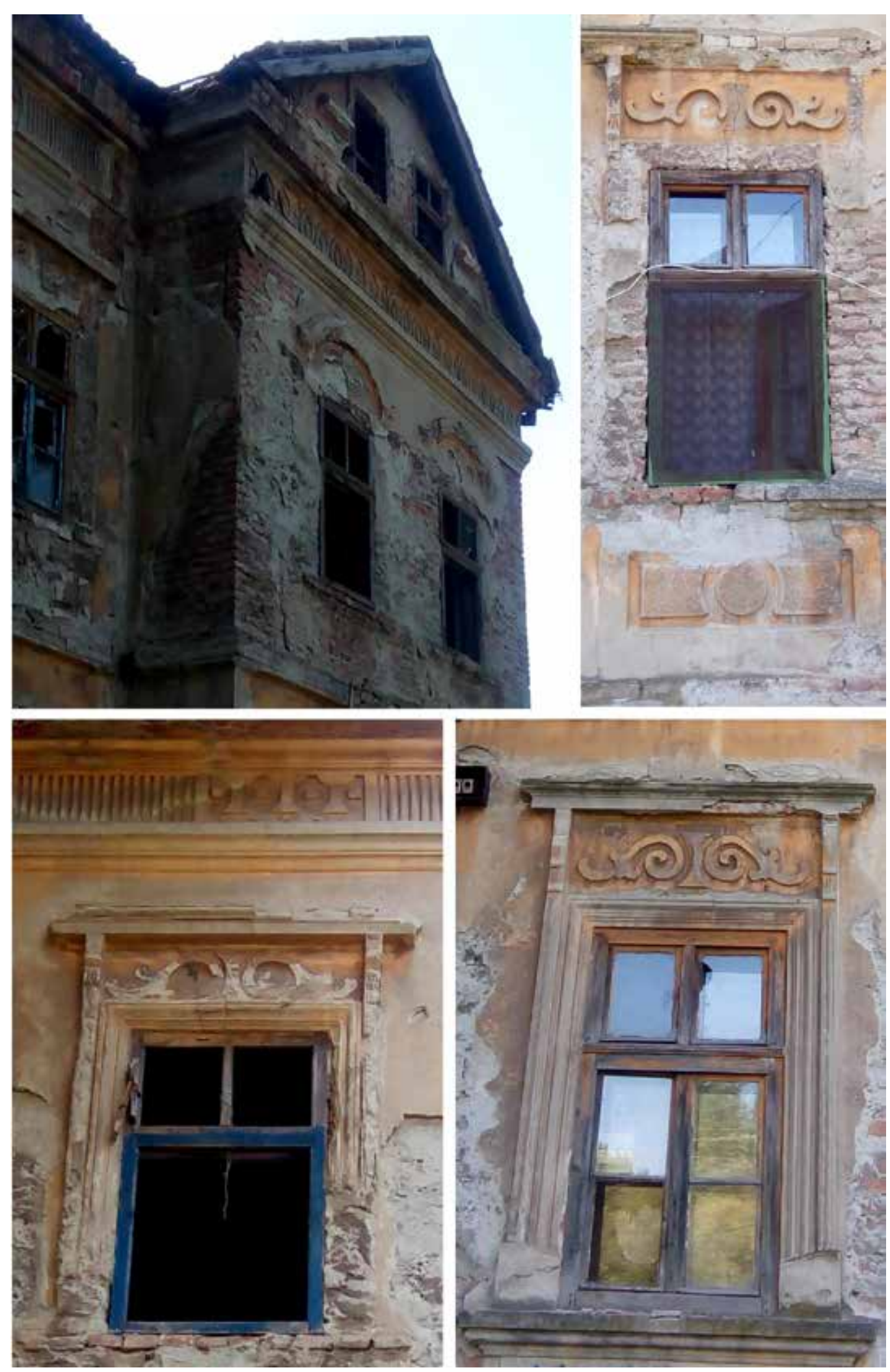

Fig. 7a. The main administrative building of the mine. Details of the facade today (the photos made by the authors in 2017). 




Fig. 8. The Church of St. George. Up left: the Church soon after it was built (Bogdanović 1928, 68); down left and right: the Church today (the photos made by the authors in 2017).

tive in Kostolac town (manuafactured in USA in 1945 and operating in the area from 1948 to 1997), and the mentioned entrance whose mining bell was stolen a few years ago (Nikolić 2018: 402-403; Спасић-Ђурић 2012a: 1-2; Đurić, Spasić-Đurić 2018). The older locomotive, once also operating in Kostolac, produced in Philadelphia in 1916/1917 and bearing the nickname "Two-headed Dragon" and the name "Kostolac", is one of the valuable exhibits of the Railway Museum Belgrade, being declared cultural property and one of only two remaining locomotives of the type in the world. It was used on the Salonica front for the needs of the allies, and in 1940 was brought by the Germans to Kostolac, where it worked until 1951. "Kostolac" was exhibited in 2018 in Paris on the occasion of a centenary since the end of the First World War (Железнице Србије ад 2019; Политика 2017; Đurić, Spasić-Đurić 2018). There is also a mine clock under prior protection as a valuable industrial product from 1900, located in the tower of a building in the town of Kostolac, 
but almost unknown to local people. According to old community photographs, this clock originally operated in the building of the mining community, being one of its important symbols (СпасићЂурић 2012a: 1-2) (Fig. 12).

The central plateau above the village of Kostolac includes the remains of the medieval town of Braničevo, the endowment Church, as well as a sacred tree as part of village religious rituals (Fig. 1). Based on the connections between these elements and those in their immediate surroundings, including the magnificent Danube, Viminacium archaeological site and several monasteries, many stories can emerge, as well as a concept for presenting the entire ladscape (Fig. 13). The story of the secondary use of ancient Viminacium elements as spoliae can further take us to the nearby monasteries where they were built in (cf. Milovanović and Anđelković Grašar 2017: 167-182), learning also stories about local cults, which bring us to the village church on the plateau. The role of its founder in the functioning of Kostolac mine connects us not only to underground mining and its community, but also to "crvenka" and its use in ancient Viminacium (Nikolić 2018: 430-432). The exploitation of this natural building material in the bed adjacent to the underground mine has been stopped, and after the past demolition of some of the community buildings, a spacious plateau between the entrance to the old shaft and the deposit itself retained, which can be used in future for creative presentations of the area (Nikolić and Roter-Blagojević 2018: 788-789). In the Czech Republic, this material is often called "červenka" (Itras), and with the knowledge that the Czechs were some of the first miners to settle in Kostolac, new stories can emerge (Nikolić 2018: 445; Nikolić, Tapavički-Ilić and Delić-Nikolić, in print; Nikolić and Anđelković Grašar, forthcoming).

Such storytelling links nature and local beliefs, as well as the development of the techniques and technologies that came along with the remains of tangible cultural heritage. The spatial connections of these elements create short paths of history and culture for visitors across the Kostolac landscape, formed on the basis of the interconnections of its tangible and intangible heritage, where the mining history has one of the most important roles (Nikolić 2018: 430, 432). ${ }^{1}$ However, this process cannot be complete without the stories of local people. It is the last opportunity to record the tales of still living miners of the underground mine, or even their descendants, because soon it will be too late. These stories form the precious treasure of the intangible heritage of Kostolac mining history which is connected to older stories - even those of Roman Viminacium. It was Đorđe Vajfert, Dragutin Todić, mine managers and enginners as passionate antique lovers who for decades collected Viminacium stone remains left to free distribution and spread in agricultural fields, thus saving them, and afterwards leaving them to museums (Спасић-Ђурић 2015: 14).

The characteristic of small mining communities is the nature of their work - dirty and unhealthy, but nevertheless a source of pride and cohesion (Warwick and Littlejohn 1992: 30). The protection of the mining community in the village of Kostolac can be the first step in the preservation of the mining heritage of the whole Kostolac area, which includes traces of underground mining, but in the future will also include contemporary strip mining. The reconstruction of the post-industrial landscape in the German Lusatian strip mining area which introduced new tourist facilities so that the area is now visited by hundreds of thousands of visitors a year, is often received with the dissatisfaction of the local population during the process. "They are very conflicted", said one of the tour guides, because "they want to be proud of their past." He asked a question: "How to work with locals, how to celebrate the mining history and at the same time create a nice and interesting new area?

1 The authors of this paper have already stressed the enormuos potential of this region and importance for greater interconnection of the heritage within it pointing on the long process in sharing of heritage by linking the archaeological heritage of Viminacium and other heritage forms (Anđelković Grašar and Nikolić 2019: 77-98). 

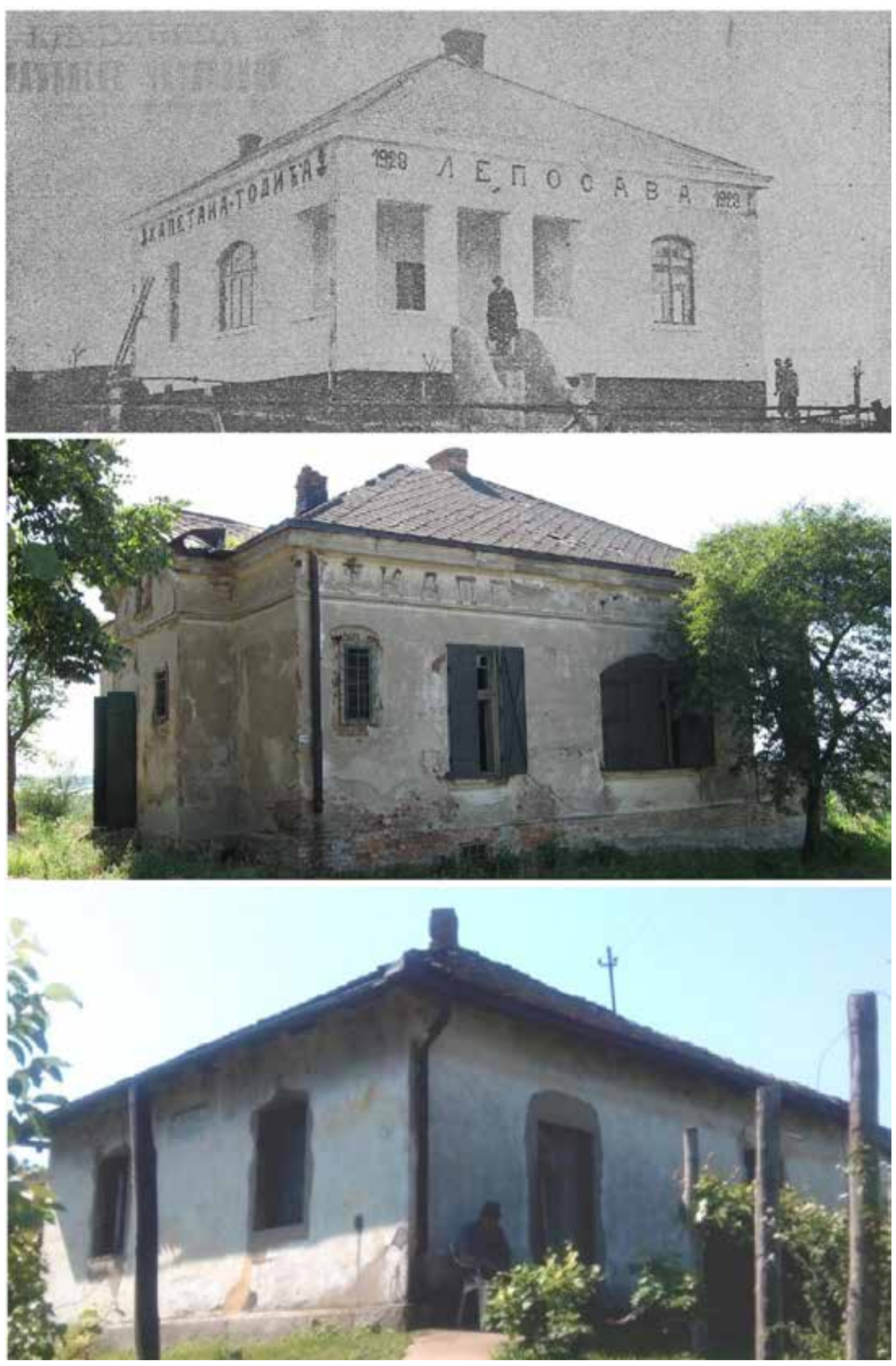

Fig. 9. The captain Todić's villa and the priest house. Up: the villa soon after it was built (Bogdanović 1928, 6); middle: the villa today (the photo made by Zoran Cekic in 2008); down: the priest house today (the photo made by the authors in 2017). 



Fig. 10. The industrial part of the mine. Up: the old glass factory (Feldić 1990, 224); middle: the view to the industrial railway from the hill above the village (EPS); down: industrial railway transporting coal to the Danube

(Simić 1971, 76). 




Fig. 11. The postcard from the beginning of the 20th century showing the buldings of the mine (Korać, Nikolić and Tapavički-Ilić 2016, 120, Fig.4). 

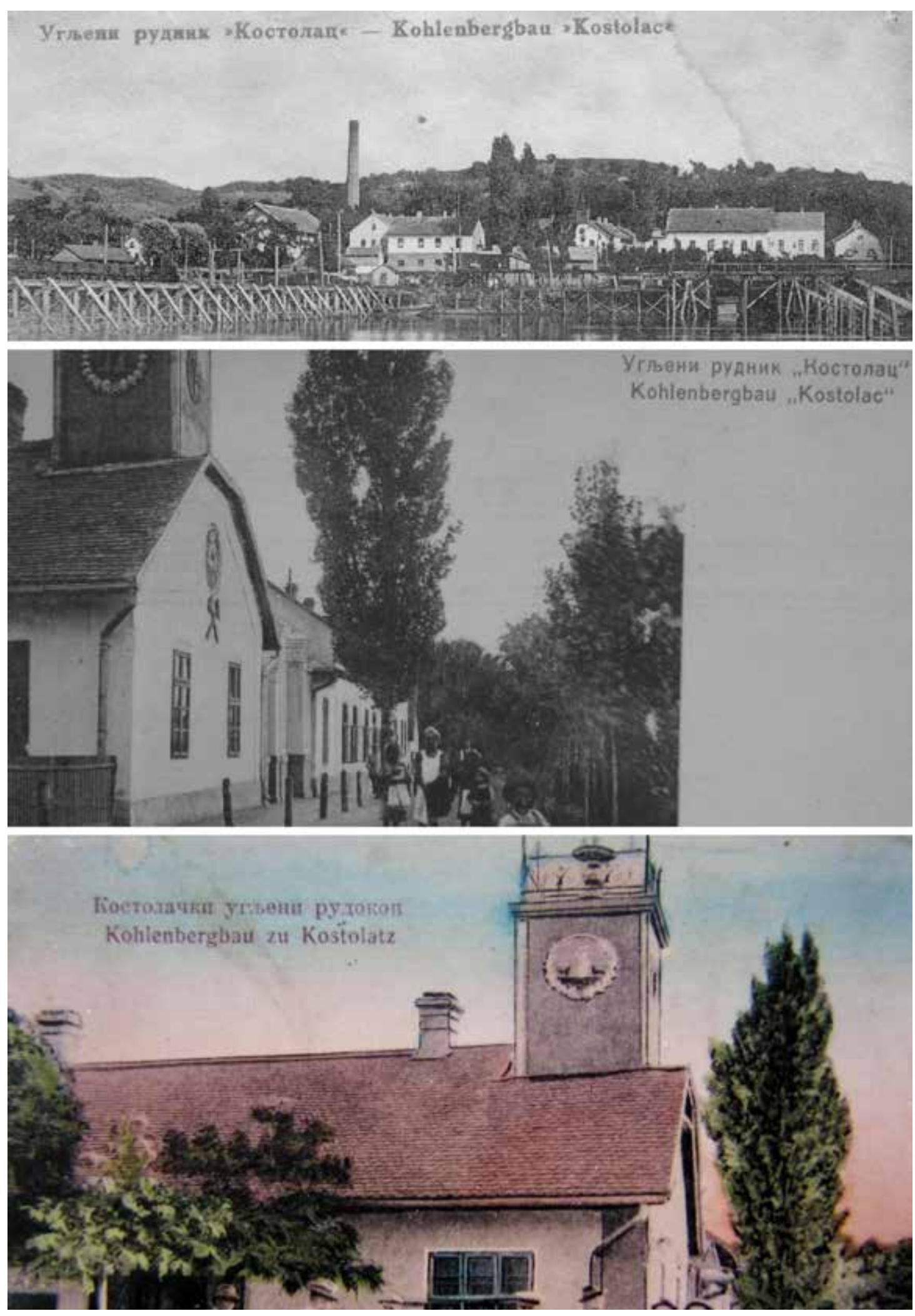

Fig. 12. The building with the clock. Up: the old mine viewed from the river with the mentioned building visible on the right in the beginning of the 20th century (Spasić-Đurić 2012b, 7); middle: the building and its neighbourhood (EPS); down: the building in the beginning of the 20th century (Spasić-Đurić 2012a, 3). 


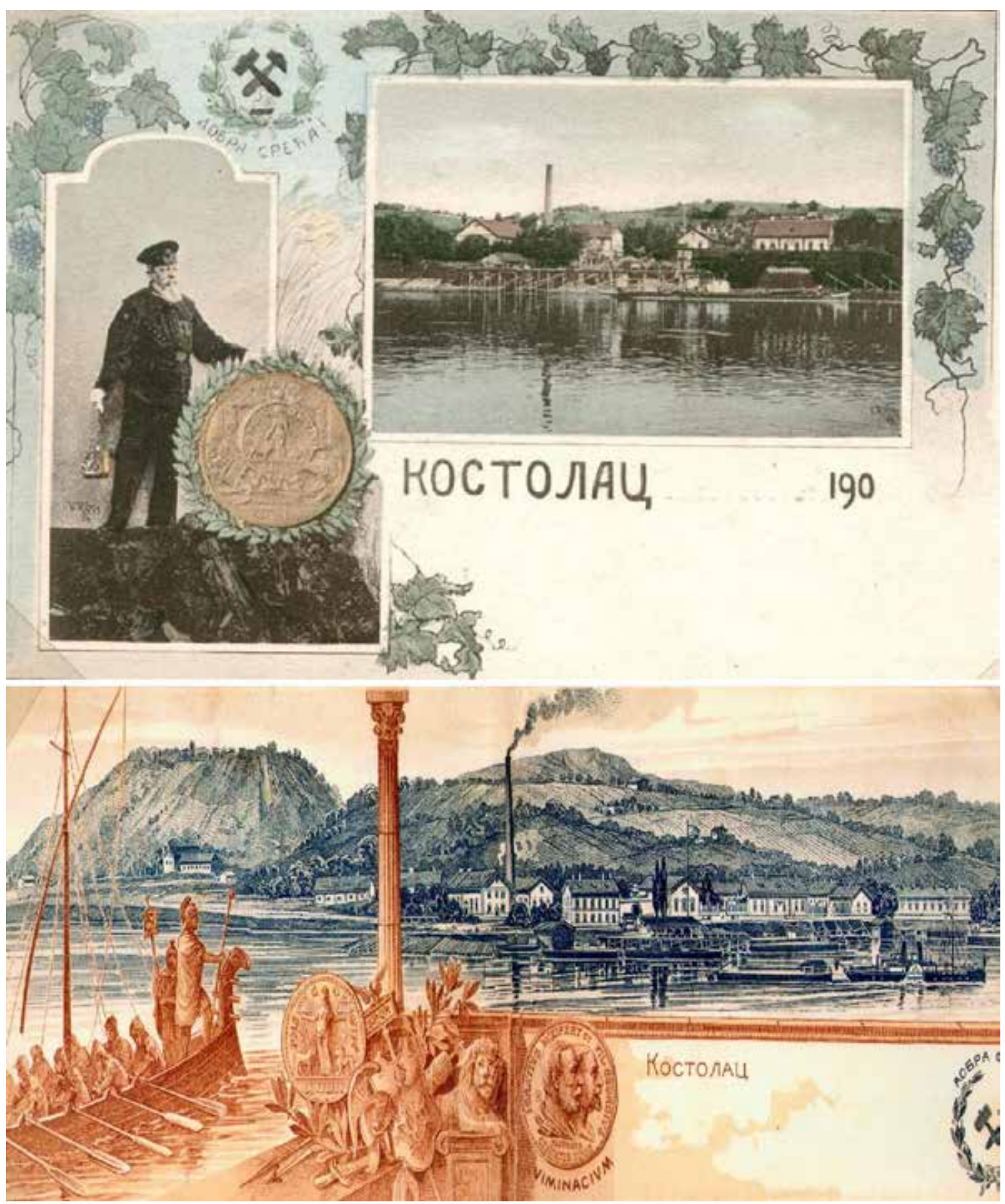

Fig. 13. The old postcards of the mine with artistic imaginations connecting mining and archaeological heritage of Kostolac area (EPS). Up: A man in ceremonial mining unform (Ignjat or Đorđe Vajfert (?)) holding the medal with ancient Viminacium coat of arms, and the view of the mine; down: the Roman fleet on the Danube coming to the old mine with the mining and Viminacium motifs connected into unity (EPS).

Their whole lives they believed this was an area where work is important. It was dirty and polluted because it had to be." (The Guardian: 2014). We can cite here the statement that "man (community) separated from the natural environment and the appropriate cultural environment, loses the natural and created impulse that creates the need to enjoy beauty", and the destruction of the natural environment and underdeveloped cultural environment creates a community "which is unresponsive and 
passively confronts beauty", "does not demand anything on the aesthetic level and subconsciously accepts the low quality of its environment" (Kurtović-Folić 2000: 129). However, a large number of residents of this German landscape hope that their future belongs to tourism (The Guardian: 2014), which necessarily brings the need for the landscaping and improvement of the natural environment. The need for beauty, as "one of the most vital psychological needs of every man", can be suppressed, but it does not cease to exist (Kurtović-Folić 2000: 129). Thus, the whole process of the possible future protection and adaptation of the Kostolac village mining community should be undertaken very carefully and consider the involment of the local community - by listening to their needs and wishes, but shaping them further with proper education about heritage values and their responsibility towards it, showing them the benefits it can bring, in any aspect of their life.

\section{CONCLUSIONS}

Activation and sustainable use of the industrial heritage of Kostolac village have to include protection and rehabilitation of historic buildings, protection and presentation of landscapes with natural resources exploitation, but also careful integration of future infrastructural interventions in the landscape, with the constant participation of the local community in heritage protection. ${ }^{2}$ Although the long-term sustainability of historic places is hard to achieve because most of them need state support everywehere in the world, we learn from statistical data that in the first decade of this century, rehabilitation of historic buildings generally created a $13 \%$ higher return on invest-

2 An important step in the involvement of the local community of Kostolac village in the protection of heritage occured with their employment in the nearby Viminacium Archaeological Park, where cultural heritage started to become sustainable and attractive to wide public which is elaborated in other contributions of the authors of this paper (Anđelković Grašar, Nikolić and Tapavički-Ilić 2020: 259-270). ments, produced 1.243 times less waste, and created $16.5 \%$ more jobs than new constructions, while the sector of cultural heritage created from 10 to 26.7 jobs for each direct one, generating in Europe incomes in trade and services of 335 billion euros per year (Nypan 2008: 59). Thus, the solution for the succesful functioning of rehabilitated areas of cultural heritage can be found in the so called "constructive conservation", when the protection and adaptation of historic buildings is done through "actively managing change". This promotes balance between the safeguarding of the unique building's qualities and its change, seeking for a result which can be attractive in architectural and commercial terms (Catling 2013: 4). In the other words, the aim of the reuse of industrial cultural heritage includes the preservation of its values, but in a way which allows its use in modern times (Roter-Blagojević and Tufegdžić 2016: 152). The partnership between different stakeholders is a must here (Catling 2013: 6) The decisive role of tourism is also inevitable, which, in the case of Kostolac area, can bring numerous opportunities for the entire area development when coal mining is completed. However, we must remember that possible future processes in the village, including the careful renovation of the old mining community, must also bring back a sense of pride to the local population - the members of the last generations of miners who worked in the underground mining until 1966 and still live in the village and the town of Kostolac, but also to their descendants who lived a hard mining life along with their fathers and grandfathers (Nikolić 2018: 512). They should all help in the future development of "a community that is built on the pride, strength and power originating from its cultural and historical heritage" (Korać, Nikolić and Tapavički-Ilić 2016: 122).

The old undergroung mine in the village of Kostolac was founded 150 years ago. The ruined remains of the mining community may not look today like buildings we are used to calling monuments. However, they are monuments - of a 
historic period, of the region's development, and to the destinies of different peoples that lived and worked here. Looking at these buildings, it seems impossible to repair them, and many questions arise about the possibilities of their protection and presentation. During such thinking, we realize that the tangible heritage elements of the village cannot be separated from the intangible ones that cannot be strictly determined by time and space, since some of them are common to a number of temporally and spatially distant activities (Nikolić 2018: 170).

The old mining community is valuable industrial heritage of Kostolac, Požarevac, as well as of Serbia, which is supported by its various mutually interconnected tangible and intangible values. The old underground mine and its mining community now represent industrial heritage, just as the industrial architecture of modern mining and electricity generation in Kostolac area is likely to represent it in the future. However, if we do not protect the heritage we have today, we will not recognize the future one as such. We would wish that this paper could be a small contribution to the preservation of the mining community in the village of Kostolac, hoping that the officials in Serbia will more seriously recognize the values of this extremely important industrial heritage before it is too late. It is our obligation towards the local people, towards their memories, and towards their mining past which is unseparable from their lives, and thus, the life of Kostolac village.

Acknowledgements: The authors of the paper are grateful to Dragana Spasić-Đurić and Dejan Radovanović for their valuable advice on the research given in the paper and peer support.

\section{BIBLIOGRAPHY}

\section{Акциони план 2015}

Акциони план за унапређење положаја Рома на територији Града Пожаревия за период 20162020. године, Пожаревац: Град Пожаревац.

(Akcioni plan 2015

Akcioni plan za unapređenje položaja Roma na teritoriji Grada Požarevca za period 2016-2020. godine, Požarevac: Grad Požarevac).

\section{Анђелковић, В. 2010}

140 година рудника Костолач 1870-2010, Костолац: ПД ТЕ-КО Костолац.

(Anđelković, V. 2010

140 godina rudnika Kostolac 1870-2010, PD Kostolac: TE-KO Kostolac).

Anđelković Grašar, J.. Rogić, D. and Nikolić, E. 2013

Viminacium, Archaeological Park - Modern Code for Re-Reading the Past of the Roman City and Legionary Camp, in: Studies on Disasters, Catastrophes and the Ends of the World in Sources, Acta Archaeologica Pultuskiensia vol. IV, J. Popielska-Grzybowska and J. Iwaszczuk, eds., Pultusk: Pultusk Academy of Humanities, 267-271.

\section{Anđelković Grašar, J. and Nikolić, E. 2019}

Milena Pavlović Barilli's Pictorial Poetics and Viminacium Landscape, Archaeology and Science 15:77-98.

\section{Anđelković Grašar, J., Nikolić, E. and Tapavič-} ki-Ilić, M. 2020

Viminacium Archaeological Park as an Instrument of Integration of the Local Community into the Protection of Cultural Heritage, in: Roma ed il Mondo Adriatico. Della Ricecra Archeologica alla Pianificazione del Territorio. Atti del Convegno, Macerata (18-20 Maggio 2017) voll. I, R. Perna, et al., eds., Roma: Edizioni Quasar, 259-270. 


\section{Богдановић, К. С. 1928}

Драгутин В. Тодић, велики хришћанин и родољуб, Београд: Јединство.

(Bogdanović, K. S. 1928

Dragutin V. Todić, veliki hrišćanin i rodoljub, Beograd: Jedinstvo).

\section{Catling, C. 2013}

Constructive Consservation. Sustainable Growth for Historic Places, Swindon: English Heritage.

\section{Čizler, J. 2014}

Industrijsko nasleđe kao potencijal za razvoj kreativne ekonomije, in: Kreativna \& Kolaborativna ekonomija i lokalni razvoj, ed. A. Đerić, Beograd: Academica, 21-31.

\section{D’Amato, R. and Spasić-Đurić, D. 2018}

The Phrygian Helmet in Byzantium - Archaeology and Iconography in the Light of Recent Finds from Braničevo, Acta Militaria Mediaevalia XIV: 29-67.

Димитријевић Марковић, С. и Сретеновић, И. 2008

Београдска “Фабрика шећера“- могућности и проблеми рехабилитације, Наслеђе IX: 267276.

(Dimitrijević Marković, S. i Sretenović, I. 2008 Beogradska "Fabrika šećera"-mogućnosti i problemi rehabilitacije, Nasleđe IX: 267-276).

\section{Dukić, M. 2012}

Industrijsko nasleđe: Kontraevolucija, Biznis i finansije 90/2012:70-73.

Ђокић, Д. и Јацановић, Д. 1992

Топографска грађа Стига, Viminacivm 7: 61110.

(Đokić, D. i Jacanović, D. 1992

Topografska građa Stiga, Viminacivm 7: 61-110).

\section{Đurić, R. i Spasić-Đurić, D. 2018}

Parne lokomotive - simboli industrijskog nasleđa
Kostolca, in: Zaštita životne sredine i održivi razvoj "Energetika i rudarstvo 2018”, 6. savetovanje sa međunarodnim učešćem, zbornik radova, ed. M. Ignjatović, Beograd: Privredna komora Srbije

\section{ERIH}

Senje Coal Mine. https://www.erih.net/i-wantto-go-there/site/senje-coal-mine?\&tx_erihsites_ erihmap[getVars][country]=32 (accesed on October 15h, 2020).

\section{EPS}

Istorija., http://www.eps.rs/lat/kostolac/Stranice/ istorija-teko.aspx (accessed on November 25th, 2020).

\section{Фелдић, Д. 1971}

Домови и људи, in: Здружено електропривредно предузеће Србије - ИЕК Костолаи 18701970, ed. С. Марковић, Костолац: Одбор за прославу сто година рудника и 25 година термоелектрана ИЕК-Костолац, 209-230.

(Feldić, D. 1971

Domovi i ljudi, in: Združeno elektroprivredno preduzeće Srbije - IEK Kostolac 1870-1970, ed. S. Marković, Kostolac: Odbor za proslavu sto godina rudnika i 25 godina termoelektrana IEK-Kostolac, 209-230).

\section{Фелдић, Д. 1990}

Фабрика стакла у Костолцу, Viminacivm, 4-5: 223-224.

(Feldić, D. 1990

Fabrika stakla u Kostolcu, Viminacivm, 4-5: 223224).

\section{Grgašević, J. 1923}

Rudarstvo u Srbiji - sa slikama rudnika i jednim dodatkom, Beograd: Jugoslovenski Lloyd.

Itras

Medlovický lom, http://itras.cz/medlovicky-lom/ (accessed on September 12 ${ }^{\text {th }}, 2020$ ) 


\section{Јовановић, П, Паклар, Д. и Ћосић, С. 1971}

26 милиона тона, in: Здружено електропривредно предузеће Србије - ИЕК Костолаи 1870-1970, ed. С. Марковић, Костолац: Одбор за прославу сто година рудника и 25 година термоелектрана ИЕК-Костолац, 93-114.

(Jovanović, P, Paklar, D. i Ćosić, S. 1971

26 miliona tona, in: Združeno elektroprivredno preduzeće Srbije - IEK Kostolac 1870-1970, ed. S. Marković, Kostolac: Odbor za proslavu sto godina rudnika i 25 godina termoelektrana IEK-Kostolac, 93-114).

\section{Каниц, Ф. 1989}

Србија: Земља и становништво од римског доба до краја 19. века, прва књига, Београд: Српска књижевна задруга.

(Kanic, F. 1989

Srbija: Zemlja i stanovništvo od rimskog doba do kraja 19. veka, prva knjiga, Beograd: Srpska književna zadruga).

\section{Korać, M. et al. 2014}

Roman Limes in Serbia, Belgrade: Institute of Archaeology.

Korać, M., Nikolić, E. and Tapavički-Ilić, M. 2016

Archaeological park of Viminacium: Beautifying a Community by Cultural Heritage, Archaeology and Science 11/2015:109-126.

Korać, M. and Mikić, Ž. 2014

Antropološka kolekcija Viminacium I: nekropola Pećine. Centar za nove tehnologije Viminacium i Arheološki institut, Beograd.

\section{Kurtović-Folić, N. 2000}

Princip “održivosti” i zaštita graditeljskog nasleđa, in: Principi i praksa održivosti u razvoju naselja u Srbiji 2, eds. R. Bogdanović and B. Stojkov, Beograd: Udruženje urbanista Srbije, 127-155.

\section{Марковић, С. (ed.) 1971}

Здружено електропривредно предузеће Србије - ИЕК Костолаи 1870-1970, ed. С. Марковић, Костолац: Одбор за прославу сто година рудника и 25 година термоелектрана ИЕККостолац.

(Marković, S. ed.) 1971

Združeno elektroprivredno preduzeće Srbije - IEK Kostolac 1870-1970, ed. S. Marković, Kostolac: Odbor za proslavu sto godina rudnika i 25 godina termoelektrana IEK-Kostolac).

Milovanović, B. and Anđelković Grašar 2017 Female Power That Protects: Examples of the Apotropaic and Decorative Functions of the Medusa in Roman Visual Culture from the Territory of the Central Balkans, Starinar LXVII: 167-182.

Nikolić, E. 2013

Contribution to the Study of Roman Architecture in Viminacium: Construction Materials and Building Techniques, Archaeology and Science 8/2012: 21-48.

Nikolić, E. and Anđelković Grašar, J., forthcoming

Arheološki park Viminacium i Živa Award 2018, in Arheologija u Srbiji: projekti Arheološkog instituta u 2018. godini, ed. S. Vitezović, Beograd: Arheološki institut.

Nikolić, E. et al. 2015

Role of Brick in Hydraulicity of Viminacium Mortars. Decorative Mortars of Thermae, Archaeology and Science 10/2014: 71-92.

Nikolić, E. 2018

Construction, Deconstruction and reconstrucion of Viminacium: Context and Concept. Unpublished PhD Thesis, Faculty of Architecture, University of Belgrade. 
Nikolić, E., Anđelković Grašar, J. and Rogić, D. 2017

Viminacium: Research, Protection and Recognition, in: Preserving transcultural heritage: your way or my way? (ed. J. R. dos Santos, Lisbon: ARTIS - Institute of Art History from School of Arts and Humanities of the University of Lisbon and the ICOMOS Portugal, 574-583.

Nikolić, E., Tapavički-Ilić, M. and Delić-Nikolić, I., in print

Viminacium - Landscape and Heritage (Trans) Formation, in: Handbook of Cultural Heritage Analysis, eds., S. D'Amico and V. Venuti, Berlin: Springer.

\section{Nikolić, E. and Roter-Blagojević, M. 2018}

Cultural Landscape of Ancient Viminacium and Modern Kostolac - Creation of a New Approach to the Preservation and Presentation of its Archaeological and Industrial Heritage, in: Conference Proceedings, 5th International Academic Conference on Places and Technologies 2018, eds. A. Krstić-Furundžić et al., Belgrade: Faculty of Architecture, University of Belgrade, 785-792.

\section{Nypan, T. M. 2008}

The Economics of Built Heritage, in: Cultural Heritage and Tourism: Potential, Impact, Partnership and Governance, ed. M. Lehtimäki, Vilnius: Department of Cultural Heritage under Ministry of Culture, 59-61.

\section{Одлука 1979}

Одлука о утврђивању непокретних културних добара од изузетног значаја и од великог значаја, Службени гласник СРС бр.14/1979.

(Odluka 1979

Odluka o utvrđivanju nepokretnih kulturnih dobara od izuzetnog značaja i od velikog značaja, Službeni glasnik SRS br.14/1979).

\section{Одлука 2009}

Одлука о утврђивању локалитета Виминацијум у атару села Стари Костолац за археолошко налазиште, Службени гласник РC, 102/2009.

(Odluka 2009

Odluka o utvrđivanju lokaliteta Viminacijum u ataru sela Stari Kostolac za arheološko nalazište, Službeni glasnik RS, 102/2009).

\section{Пејић, Б. и Јаношевић, Д. 1971}

Беочуг столећа, in: Здружено електропривредно предузеће Србије - ИЕК Костолаи 18701970, ed. С. Марковић, Костолац: Одбор за прославу сто година рудника и 25 година термоелектрана ИЕК-Костолац, 57-74.

(Pejić, B. i Janošević, D. 1971

Beočug stoleća, in: Združeno elektroprivredno preduzeće Srbije - IEK Kostolac 1870-1970, ed. S. Marković, Kostolac: Odbor za proslavu sto godina rudnika i 25 godina termoelektrana IEK-Kostolac, 57-74).

\section{Попадић, J. 2017}

Ћира са Солунског фронта путује на изложбу у Париз, Политика, 27.07.2017, http://www.politika.rs/sr/clanak/385611/Cira-sa-Solunskog-fronta-putuje-na-izlozbu\%20-u- Pariz/ (accesed on November $\left.15^{\text {th }}, 2020\right)$.

(Popadić, J. 2017

Ćira sa Solunskog fronta putuje na izložbu u Pariz, Politika, 27.07.2017, http://www.politika. rs/sr/clanak/385611/Cira-sa-Solunskog-fronta-putuje-na-izlozbu\%20-u- Pariz/ (accesed on November $\left.15^{\text {th }}, 2020\right)$ ).

Поповић, М. и Иванишевић, В. 1988

Град Браничево у средњем веку, Старинар XXXIX: 125-179.

(Popović, M. i Ivanišević, V. 1988

Grad Braničevo u srednjem veku, Starinar XXXIX: 125-179).

\section{Просторни план 2012}

Просторни план подручја Града Пожаревца, Службени гласник Града Пожаревиа 10/2012. (Prostorni plan 2012 
Prostorni plan područja Grada Požarevca, Službeni glasnik Grada Požarevca 10/2012).

\section{Просторни план 2015}

Просторни план подручја посебне намене археолошког налазишта Виминацијум, Службени гласник РС 14/2015.

(Prostorni plan 2015

Prostorni plan područja posebne namene arheološkog nalazišta Viminacijum, Službeni glasnik RS 14/2015).

Радосављевић, М. и др. 2014

Костолачки басен пример могућег приступа одрживе површинске експлоатације угља, Рударски гласник, СXI/1-2: 55-60

(Radosavljević, M. et al.. 2014

Kostolački basen primer mogućeg pristupa održive površinske eksploatacije uglja, Rudarski glasnik, CXI/1-2: 55-60)

\section{Ratkajec, M. 2014}

Zaštita industrijske baštine na primjeru Tvornice strojeva i ljevaonice metala Braća Ševčik, Godišnjak Hrvatskog restauratorskog zavoda 5/2014:243-257.

\section{Robinson, M. 2008}

The Experences of Cultural Tourism, in: $\mathrm{Cul}$ tural Heritage and Tourism: Potential, Impact, Partnership and Governance, ed. M. Lehtimäki, Vilnius: Department of Cultural Heritage under Ministry of Culture, 18-25.

\section{Ромелић, Ж. 2000}

Рударски станови у североисточној Србији, Гласник Етнографског института 49: 225230.

(Romelić, Ž. 2000

Rudarski stanovi u severoistočnoj Srbiji, Glasnik Etnografskog instituta 49: 225-230).

Roter-Blagojević, M. and Tufegdžić, A. 2016

The New technology Era Requirements and Sus- tainable Approach to Industrial Heritage Renewal, Energy and Building 115: 148-153.

\section{Симић, В. 1971}

Две трећине века, in: Здружено електропривредно предузеће Србије - ИЕК Костолаи 1870-1970, ed. С. Марковић, Костолац: Одбор за прославу сто година рудника и 25 година термоелектрана ИЕК-Костолац, 75-92.

(Simić, V. 1971

Dve trećine veka, in: Združeno elektroprivredno preduzeće Srbije - IEK Kostolac 1870-1970,

ed. S. Marković, Kostolac: Odbor za proslavu sto godina rudnika i 25 godina termoelektrana IEK-Kostolac, 75-92).

\section{Спасић-Ђурић, Д. 2012а}

Прилог проучавању историје рударства у Костолцу, Мајдан 2/2012: 1-9.

(Spasić-Đurić, D. 2012a

Prilog proučavanju istorije rudarstva u Kostolcu, Majdan 2/2012: 1-9).

\section{Спасић-Ђурић, Д. 2012b}

Утицај рударства и енергетике на археолошке локалитете у регији Костолца, Зборник радова Високе Техничке школе Пожареваи 1-2: 9-12. (Spasić-Đurić, D. 2012b

Uticaj rudarstva i energetike na arheološke lokalitete u regiji Kostolca, Zbornik radova Visoke Tehničke škole Požarevac 1-2: 9-12).

\section{Спасић-Ђурић, Д. 2015}

Град Виминачијум, Пожаревац: Народни музеј Пожаревац.

(Spasić-Đurić, D. 2015

Grad Viminacijum, Požarevac: Narodni muzej Požarevac).

\section{Spasić-Đurić, D and Jovanović, S. 2018}

A 12th Century Set of Marvered Purple Glass Vessels from Braničevo, Старинар (Starinar) LXVIII, 151-173. 


\section{Стојковић, С. J. 1893}

На лепом српском Дунаву од Београда до Радујевиа, Београд: Штампарија Краљевине Србије.

(Stojković, S. J. 1893

Na lepom srpskom Dunavu od Beograda do Radujevca, Beograd: Štamparija Kraljevine Srbije).

\section{Стратегија 2009}

Стратегија одрживог развоја Града Пожаревиа 2009-2013 године, Пожаревац: Град Пожаревац.

(Strategija 2009

Strategija održivog razvoja Grada Požarevca 2009-2013 godine, Požarevac: Grad Požarevac).

\section{Шегрт, М. 1971}

Игре, песме књиге, in: Здружено електропривредно предузеће Србије - ИЕК Костолач 1870-1970, ed. С. Марковић, Костолац: Одбор за прославу сто година рудника и 25 година термоелектрана ИЕК-Костолац, 213-248.

(Šegrt, M. 1971

Igre, pesme knjige, in: Združeno elektroprivredno preduzeće Srbije - IEK Kostolac 1870-1970, ed. S. Marković, Kostolac: Odbor za proslavu sto godina rudnika i 25 godina termoelektrana IEK-Kostolac, 213-248).

\section{The Guardian 2014}

Life after lignite: how Lusatia has returned to nature, 10.09.2014“, https://www.theguardian.com/ environment/2014/sep/10/lusatia-lignite-mining-germany-lake-district (acessed on November 8st, 2020).

\section{Толстој, С. и Раденковић, Љ. 2001}

Словенска митологија, енциклопедијски речник, Београд: Zepter Book World.

(Tolstoj, S. i Radenković, Lj. 2001

Slovenska mitologija, enciklopedijski rečnik, Beograd: Zepter Book World).

\section{UNESCO WHS List}

Frontiers of the Roman Empire“, http://whc.unesco. org/en/list/430 (acessed on November 8th, 2020)

\section{Večernje Novosti Online 2015}

Večernje Novosti Online. "Divi se liku i delu druga Tita, 18.10.2015“, www.novosti.rs/vesti/srbija.489.html:572388-Divi-se-liku-i-delu-druga-Tita (acessed on October 15th, 2020)

\section{Влашковић, Р. и Славковић, М. 1971}

Светло с велике реке, in: Здружено електропривредно предузеће Србије - ИЕК Костолач 1870-1970, ed. С. Марковић, Костолац: Одбор за прославу сто година рудника и 25 година термоелектрана ИЕК-Костолац, 115-130.

(Vlašković, R. i Slavković, M. 1971

Svetlo s velike reke, in: Združeno elektroprivredno preduzeće Srbije - IEK Kostolac 1870-1970, ed. S. Marković, Kostolac: Odbor za proslavu sto godina rudnika i 25 godina termoelektrana IEK-Kostolac, 115-130).

\section{Вуловић, Г. 1939}

Путовођа (адресар) кроз Пожареваи и срез, Пожаревац: Штампарија Ђорђа Наумовића.

(Vulović, G. 1939

Putovođa (adresar) kroz Požarevac i srez, Požarevac: Štamparija Đorđa Naumovića).

\section{Вучетић, М. 2010}

Из историје српских угљенокопа: Јаме костолачког мајдана, Београд: ЈП Електропривреда Србије.

(Вучетић, М. 2010

Из историје српских угљенокопа: Јаме костолачког мајдана, Београд: ЈП Електропривреда Србије).

Warwick, D. and Littlejohn, G. 1992

Coal, Capital and Culture. Sociological Analysis of Mining Communities in West Yorkshire, Routledge, London. 
Зечевић, С. 1981

Митска бића српских предања, Београд: Вук Караџић.

(Zečević, S. 1981

Mitska bića srpskih predanja, Beograd: Vuk Karadžić).

\section{Железнице Србије ад 2019}

Локомотива Костолац стигла у Париз на обележавање победе у Великом рату, http:// www.zeleznicesrbije.com/lokomotiva-kostolac-stigla-u-pariz-na-obelezavanje-pobede-u-velikom-ratu/?lang=lat (accessed on November 8th, 2020).

(Železnice Srbije ad 2019

Lokomotiva Kostolac stigla u Pariz na obeležavanje pobede u Velikom ratu, http://www. zeleznicesrbije.com/lokomotiva-kostolac-stigla-u-pariz-na-obelezavanje-pobede-u-velikom-ratu/?lang=lat (accessed on November 8th, 2020)).

\section{REZIME}

\section{NASLEĐE PRED KOJIM} ŽMURIMO: STARA RUDARSKA KOLONIJA U SELU KOSTOLAC, SRBIJA

KLJUČNE REČI: SELO KOSTOLAC, RUDARSKA KOLONIJA, RUDARSKO NASLEĐE, INDUSTRIJSKO NASLEĐE, PODZEMNI RUDNIK, RUDNIK UGLJA.

Iako je Viminacijum već godinama međunarodno poznato i priznato arheološko nalazište koje se nalazi na teritoriji sela Kostolac (Stari Kostolac), ali i turistički potencijal regiona Grada Požarevca i čitave Srbije, osvešćivanje o celokupnom kulturnom nasleđu ovog sela na nivou lokalne zajednice i šire javnosti deluje kao neizvestan i težak proces. Predeo sela Kostolac u severoistočnoj Srbiji i zaleđu Dunava važan je sa aspekta arheološkog nasleđa, ali i industrijskog nasleđa iz prethodna dva veka, koje je sačuvano kroz različite materijalne ostatke i nematerijalno nasleđe vezano za viševekovnu rudarsku aktivnost u ovom kraju.

Ove godine obeležava se 150 godina od otvaranja podzemnog rudnika i početka eksploatacije uglja u selu Kostolac, što je u isto vreme i jubilej industrijalizacije moderne Srbije 1870. godine. Nažalost, suprotno važnosti ovog jubileja, građevine rudarske kolonije čiji su nekadašnji stanovnici bili učesnici i svedoci modernizacije i razvoja tadašnje države, potpuno su ruinirane i polako nestaju pred očima meštana i stručne javnosti, nakon zatvaranja podzemnog rudnika 1966. godine. Kasniji ubrzani razvoj savremenog površinskog kopa uglja „Drmno“ i otvaranje termoelektrane „Kostolac B”, pažnju privrede, pa tako i šire javnosti vezanu za eksploataciju uglja u ovom predelu, usmerio je u drugom pravcu, potpuno zanemarujući vrednost rudarskog nasleđa iz 19. veka u selu Kostolac, pa se prostor rudarske kolonije zaobilazi i u saobraćaju i dnevnoj komunikaciji. Takođe, mnogi duhovni elementi života stanovnika sela oblikovani su pod uticajem aktivnosti rudnika, a do danas nisu šire prepoznati kao vrednosti, iako predstavljaju veoma značajno nematerijalno nasleđe celog regiona.

Ostaci stare rudarske kolonije u selu Kostolac predstavljaju vredno industrijsko nasleđe ne samo prostora Kostolca i Grada Požarevca, već i celokupne Srbije, jer prikazuju vezu materijalnog i nematerijalnog nasleđa: ostataka graditeljstva, eksploatacije prirodnih resursa sa rudarenjem, interkulturalnih dijaloga doseljenika rudara i njihovih porodica sa starosedeocima, verovanja i običaja, legendi i mitova. Autorke su ovim tekstom želele da ukažu i ponovo skrenu pažnju naučne i stručne javnosti, zvaničnika i institucija, na važnost rudarskog nasleđa ovog kraja, potrebu njegove zaštite i potencijal buduće prezentacije prostora rudarske kolonije sela Kostolac, u cilju socio-ekonomskog i kulturnog razvoja lokalne zajednice, dok ne bude kasno da se bilo šta učini. 
Arheologija i prirodne nauke (Archaeology and Science) is an Open Access Journal. All articles can be downloaded free of charge and used in accordance with the licence Creative Commons - Attribution-NonCommercial-NoDerivs 3.0 Serbia (https://creativecommons.org/licenses/ by-nc-nd/3.0/rs/.

Časopis Arheologija i prirodne nauke je dostupan u režimu otvorenog pristupa. Članci objavljeni u časopisu mogu se besplatno preuzeti sa sajta i koristiti u skladu sa licencom Creative Commons - Autorstvo-Nekomercijalno-Bez prerada 3.0 Srbija (https://creativecommons.org/ licenses/by-nc-nd/3.0/rs/. 